\title{
A NOVA (MODERNA) BIOLOGIA E A GENÉTICA NOS LIVROS DIDÁTICOS DE BIOLOGIA NO ENSINO MÉDIO*
}

\author{
New Biology and genetics in High School \\ science textbooks
}

\author{
Márcia Cristina Fernandes Xavier ${ }^{1}$ \\ Alexandre de Sá Freire ${ }^{2}$ \\ Milton Ozório Moraes ${ }^{3}$
}

\begin{abstract}
Resumo: Pesquisas têm demonstrado que o livro didático tem papel determinante na organização curricular e na prática pedagógica dos professores. O livro didático precisa, como sugerem os Parâmetros Curriculares Nacionais do Ensino Médio (PCNEM), contemplar conhecimentos modernos em um contexto de historicidade, discutindo, paralelamente, temas de apelo social. Esta pesquisa analisou os livros didáticos de acordo com o padrão de atualização, utilizando a Biologia como modelo. Os resultados sugerem que os atuais livros didáticos não estão atualizados no estudo dos temas considerados essenciais para perfeito entendimento e aquisição de informações associadas ao rápido avanço do conhecimento na área da Nova Biologia. Aponta-se para o fato de que necessitam de reformulação e atualizações com textos modernos, que promovam mudanças conceituais.
\end{abstract}

Palavras-chave: livro didático. Nova Biologia. Ensino Médio.

\begin{abstract}
Recent research has demonstrated that Science textbooks have a determining role in curricular organization and that teachers use them to compose their classes, activities, and exams. The National Programs for High School Curriculum Parameters (PCNEM) has infuenced Brazilian education since 1999, bringing updated concepts of Biology and genetics, including themes such as transgenics, gene therapy, cloning, stem cell and paternity testing into the curriculum. The teaching of High School is challenging because of the need to contemplate both classic and modern knowledge within a historical context that simultaneously discusses appealing social themes. The current study analyzed how up-to-date the current High School textbooks are, using the Biology as a model. The themes included in the so-called New Biology was analyzed because they are essential to a good understanding of modern concepts of great social significance. The results suggest that the current textbooks are not up-to-date concerning the themes considered essential for perfect understanding and acquisition of suitable information which is part of the fast progress of knowledge in the area of New Biology and need reformulation and updating, through the introduction of current modern themes that promote conceptual change.
\end{abstract}

Key words: didactic book, new biology, High School teaching.

\footnotetext{
* O artigo reflete parte do projeto de mestrado desenvolvido por Márcia Cristina Xavier sob orientação do Dr. Milton Ozório Moraes, Programa de Pós-Graduação de Ensino em Biociências e Saúde (PPG-EBS), Fundação Oswaldo Cruz. (Fiocruz).

${ }^{1}$ Mestranda, PPG-EBS, Fiocruz: E-mail: marciaxavier2001@yahoo.com.br

${ }^{2}$ Doutorando, PPG-EBS, Fiocru\%. E-mail: alefreire2001@yahoo.com.br

${ }^{3}$ Pesquisador Adjunto, Laboratório de Hanseniase, Departamento de Micobacterioses, Instituto Oswaldo Cru₹, Fiocruz.

E-mail:mmoraes@fiocruz.br
} 


\section{O livro didático no contexto atual}

Os livros didáticos são objetos pedagógicos importantes no ensino (Macedo, 2004) e, presentes na maioria das escolas, dão suporte no processo de formação dos cidadãos (Vasconcelos e Souto, 2003). Estudos na área demonstram que o livro didático exerce papel determinante na organização curricular (Gayán e Garcia, 1997) e é base para o preparo de materiais (como apostilas) inseridos no contexto escolar (Núñes et al., 2003). O livro didático é a pedra fundamental no processo de formação dos alunos (Vasconcelos e Souto, 2003) devendo, então, ser objeto de constante pesquisa na qualidade de seu serviço à educação.

\section{O livro didático no Ensino Médio}

No Brasil, o livro didático é ferramenta de ensino-aprendizagem e suporte para a organização do currículo na maioria das instituições de ensinos Fundamental e Médio do país. Portanto, para poder exercer seu papel junto à escola, esta ferramenta precisa estar atualizada, ser uma "fonte viva de sabedoria" (Núñes et al., 2003, p.1) e, concomitantemente, ter um papel decisivo para reduzir, ou mesmo eliminar, o abismo entre Ciência e cidadania (Loreto e Sepel, 2003).

De acordo com Franco (1992), a implantação do livro didático nas escolas foi oficializada em 1938, portanto, há quase setenta anos. No Ensino Fundamental, por interferência dos governos federal, estaduais e municipais, vemos a real inserção desta ferramenta devido a sua cessão gratuita durante um ano letivo ao aluno até a 8 série.

A partir do ano de 2005, mediante o Programa Nacional do Livro Didático (PNLD), tal prática foi adotada também no Ensino Médio (EM), sinalizando o envolvimento dos órgãos superiores de educação com o ensino-aprendizagem da disciplina. Porém, no EM os livros contemplados pelo programa são apenas os de Português e Matemática. O livro de Biologia só entrará no programa em 2007 e, por enquanto, o professor orienta os alunos a adquirirem por conta própria esse livro.

Em trabalho recente, verificamos que os livros disponíveis para a compra, por parte dos alunos, são predominantemente de baixo custo e de volume único, no qual os conteúdos das três séries do EM estão compactados. Alternativamente, para que os alunos possam acompanhar a disciplina ao longo do ano letivo são utilizadas cópias dos livros em forma de apostilas (Xavier et al., 2005).

O atual Programa Nacional do Livro Didático do Ensino Médio (PNLEM), instituído em 2003, estabelece que, de acordo com o Fundo Nacional Desenvolvimento Escolar (FNDE, 2001), os livros didáticos devem seguir os seguintes pressupostos: adequação de sua proposta didático-pedagógica em relação à situação de ensino-aprendizagem e aos objetivos visados; correção das informações, conceitos e procedimentos que integram e dão forma a essa proposta; sintonia com a legislação e os demais instrumentos oficiais que regulamentam e orientam a educação nacional, como as diretrizes, os parâmetros e os referenciais curriculares.

Sendo assim, podemos verificar ainda no FNDE que os livros didáticos participam efetivamente do atual contexto educativo. Neste documento observam-se méritos especiais 
dos livros didáticos em relação ao aprendizado. É fundamental, portanto, que eles estejam inseridos no contexto escolar por inteiro, perpassando os âmbitos científico, social, cultural e tecendo relações entre os conhecimentos e saberes e os novos parâmetros curriculares.

\section{Os livros didáticos, os PCNEM e a Nova Biologia}

A análise dos livros didáticos requer: "explicitação de diversas inter-relações entre aluno, professor e saber visado (PNLEM, 2002, p. 12), sempre em consonância com as orientações educacionais dos Parâmetros Curriculares Nacionais, complementados para o Ensino Médio (PCNEM), definidos pela Lei de Diretrizes e Bases da Educação Nacional (LDB-96) e regulamentados pelas Diretrizes do Conselho Nacional da Educação (98) (Brasil, 2000).

A Nova Biologia - integração entre as novas tecnologias do DNA e novas aplicações em Genética, que inclui a Biotecnologia e a Biologia Molecular - é um dos temas recorrentes na mídia desde o final dos anos 1960, embora não necessariamente esteja representado nos livros didáticos (Loreto e Sepel, 2003). O destaque que estes temas apresentam pode ser explicado pelo grande apelo social e pela influência direta na vida das pessoas. São, portanto, conteúdos relevantes no contexto escolar. Debates freqüentes, por exemplo, sobre transgênicos, terapias gênicas, clonagem, células-tronco, teste de paternidade etc vêm sendo travados e a sala de aula não pode ficar alheia às novidades ou deixar de abraçar a Nova Biologia.

As aulas de Biologia, mais especificamente Genética, têm seus conteúdos orientados a partir de diretrizes dos novos PCNEM. No entanto, em nossa recente pesquisa junto a professores de escolas públicas do Estado do Rio de Janeiro pudemos detectar que os docentes baseiam suas aulas em livros didáticos (Xavier et al., 2005) que, de modo geral, não sofreram atualização nos aspectos essenciais (Neto e Francalanza, 2003).

Os PCNEM vêm procurando sugerir reformas educacionais de acordo com a LDB (Brasil, 2000), inserindo novas visões atualizadas da Biologia, especificamente no tocante à Genética. Segundo esses documentos, dois dos seis novos temas que estruturam a disciplina de Biologia relacionam-se ao estudo e à aplicabilidade de novas tecnologias associadas ao DNA que, no contexto aqui apresentado, fariam parte do que convencionamos chamar de Nova Biologia. Entre os objetivos, podemos destacar a transferência do DNA de um organismo para outro (enzimas de restrição, vetores e clonagem molecular), a participação da engenharia genética na produção de alimentos, herbicidas, produtos farmacêuticos, hormônios, de vacinas e de medicamentos; as técnicas moleculares utilizadas para a detecção precoce de doenças genéticas; a importância dos testes de DNA para determinação da paternidade, investigação criminal ou identificação de indivíduos e a compreensão da natureza dos projetos genomas, especialmente dentro do país. Os outros temas relacionam-se ao estudo dos seres vivos e às suas interações, à qualidade de vida das populações humanas, à diversidade da vida e à sua origem e evolução. 


\section{Desenho do estudo e procedimentos de análise}

Esta pesquisa levanta dados que apontam para uma melhor caracterização e avaliação dos livros didáticos analisados. Porém não atribui julgamento de valor quanto aos procedimentos de escrita e elaboração dos textos e de outros aspectos, como a qualidade das figuras. Considerando estes exemplares instrumentos muito importantes e buscando a melhoria geral dos livros, esta pesquisa visa, ainda, analisar o padrão de atualização dos livros didáticos utilizando Biologia e Genética como parâmetros.

Buscou-se, em cada exemplar, a presença de temas associados à Nova Biologia: transgênicos, projeto genoma, clonagem de mamíferos, células-tronco, teste de paternidade, variabilidade genética, melhoramento genético, DNA recombinante, hibridação, seqüenciamento, enzimas de restrição, plasmídios, íntrons e éxons, eletroforese, PCR. Os temas foram escolhidos devido à relevância à área Nova Biologia, de acordo com as diretrizes dos PCNEM, e segundo inquérito realizado junto a professores do EM (Xavier et al., 2005) que, por meio de instrumentos de pesquisa quantitativa destacaram serem necessários ao bom entendimento das novas tecnologias que aparecem nas discussões em sala de aula. Além disso têm importância social, visto sua recorrência nos meios de comunicação de massa.

Como parâmetro também foi analisado como esses livros didáticos quantificam os temas relacionados à Genética clássica, que aborda as leis de Mendel, os grupos sangüíneos, as heranças ligadas ao sexo, a pleiotropia, a interação gênica, a polimeria, a ligação gênica, os mapas gênicos e a genética de populações (Hardy-Weinberg).

Analisaram-se 12 livros didáticos em Biologia, usuais e atuais, editados por sete editoras diferentes e disponibilizados para comércio nas editoras, incluindo seus autores e ano de edição. Os conteúdos disciplinares de todo o EM encontram-se condensados em um único volume. A editora Atual foi pesquisada, mas não apresentou livros com essas características no período estudado.

A escolha dos exemplares seguiu dois critérios: o primeiro, referente ao resultado de pesquisa realizada junto aos professores. Eles responderam a um questionário com 11 questões de múltipla escolha e a entrevistas semi-estruturadas, que formalizaram e embasaram questões pertinentes aos saberes de investigação ao ensino de Genética e da Nova Biologia. O tema livro didático foi abordado, sendo dado referencial aos autores mais utilizados e os exemplares de maior recorrência nas salas de aula foram pesquisados, numa definição livre, sem restrição a editora ou à forma do livro (Tabela 1). O segundo critério foi resultado de buscas a sítios de editoras comerciais representativas.

Deste modo, propôs-se identificar a presença do tema Nova Biologia de forma geral e dos temas específicos nos textos dos livros didáticos e quantificar o número de temas e o espaço em páginas ocupadas por esses tópicos em relação ao número de páginas total de cada exemplar. Sobre os temas específicos, também foi analisada a dimensão que cada um ocupava em cada exemplar. Em determinados aspectos inseriu-se a relação observada entre qualidade de informação e quantidade de páginas envolvidas na explicação dos conteúdos.

Também foi realizada a análise da forma como os 15 temas estavam inseridos no corpo do livro, com análise individual de cada um e identificando quantos foram abordados e quantas vezes foram citados entre os exemplares. 
A nova (moderna) Biologia e a genética...

Tabela 1. Lista dos livros selecionados e analisados.

\begin{tabular}{|c|c|c|c|c|}
\hline Obra & Editora & Autor & $\begin{array}{l}\text { Critério de } \\
\text { inclusão }\end{array}$ & $\begin{array}{l}\text { Ano de } \\
\text { edição }\end{array}$ \\
\hline A) Série Novo Ensino Médio & 1) Ática & Wilson Roberto Paulino & Pesquisa & 2002 \\
\hline $\begin{array}{l}\text { B) Fundamentos da Biologia } \\
\text { Moderna }\end{array}$ & 2) Moderna & $\begin{array}{l}\text { José Mariano Amabis e } \\
\text { Gilberto Rodrigues Martho }\end{array}$ & Pesquisa & 2002 \\
\hline C) Biologia & & $\begin{array}{l}\text { José Favaretto e Clarinda } \\
\text { Mercadante }\end{array}$ & Sítio & 2003 \\
\hline D) Biologia para o Ensino Médio & 3) Scipione & $\begin{array}{l}\text { Alba Gainotti e Alessandra } \\
\text { Modelli }\end{array}$ & Sítio & 2002 \\
\hline $\begin{array}{l}\text { E) Biologia de olho no mundo do } \\
\text { trabalho }\end{array}$ & & Sídio Machado & Sítio & 2003 \\
\hline F) Biologia & & José Luís Soares & Sítio & 1999 \\
\hline G) Biologia Essencial & 4) Saraiva & Sônia Lopes & Sítio & 2003 \\
\hline H) Biologia - curso completo & 5) IBEP-Nacional & Albino Fonseca & Pesquisa & 1998 \\
\hline $\begin{array}{l}\text { I) Sistema de ensino IBEP - } \\
\text { apostila }\end{array}$ & & Albino Fonseca & Pesquisa & 2002 \\
\hline J) Biologia em foco & 6) FTD & Wanderley Carvalho & Sítio & 2002 \\
\hline L) Biologia integrada & & Luis Carlos Cheida & Sítio & 2003 \\
\hline M) Biologia compacto & & $\begin{array}{l}\text { Demétrio Gowdak e Neide } \\
\text { Simões de Mattos }\end{array}$ & Pesquisa & 1991 \\
\hline
\end{tabular}

Os espaços foram divididos em sete categorias: citação, até dois parágrafos, até meia página, de meia página a uma página inteira, até uma página e meia, até duas páginas e mais de duas páginas. Nesta análise levou-se em conta a inserção de ilustrações e/ou esquemas adicionais ao texto, a presença ou não de ilustrações em cada tema analisado, assim como sua relação entre ilustração e ocorrência nos livros. Também foi alvo de análise investigar se essas obras inserem textos de outras fontes (jornais, revistas etc) e quais são elas. Outro ponto refere-se à quantidade de questões que cada tema insere na avaliação do material. $\mathrm{O}$ espaço citação refere-se à colocação do termo e o espaço até dois parágrafos refere-se à citação de um certo tema de forma reduzida. Para uma comparação entre os temas da Nova Biologia e a Genética dita clássica analisou-se, também, quanto cada exemplar disponibiliza de suas páginas para abordar cada um deles. O cálculo foi feito pela relação entre o total de páginas com texto Nova Biologia/total de páginas, fato observado em apenas um dos exemplares. 
Xavier, M. C. F. et al.

Destaca-se que a análise realizada está inserida numa realidade observada e quantificada com extrema clareza dos fatos, o que permitiu um vislumbre muito próximo da realidade dos livros didáticos.

\section{Resultados}

Os dados relacionam 15 temas da Nova Biologia escolhidos previamente com sua presença em 12 livros didáticos.

\section{Espaço ocupado pela Nova Biologia nos livros didáticos}

Ao quantificar o espaço total por número de páginas em cada exemplar verificou-se que o máximo foi de 3,8\% relativo a todo o conteúdo do livro (Figura 1). Três exemplares abordam $2 \%$, um deles aborda em torno de $1,5 \%$, cinco abordam em torno de $1 \%$ e um aborda $0,3 \%$. Além disso, outros dois livros não abordam nenhum dos temas em qualquer momento.

Observa-se que o exemplar C aborda percentual de 80\% dos temas, perfazendo 12 .tópicos abordados, enquanto os livros A, E e G abordam 11 tópicos, os livros J e L abordam dez temas, o livro B aborda oito, os livros D e F abordam sete, o livro M aborda dois e H e I nada abordam (Figura 2).

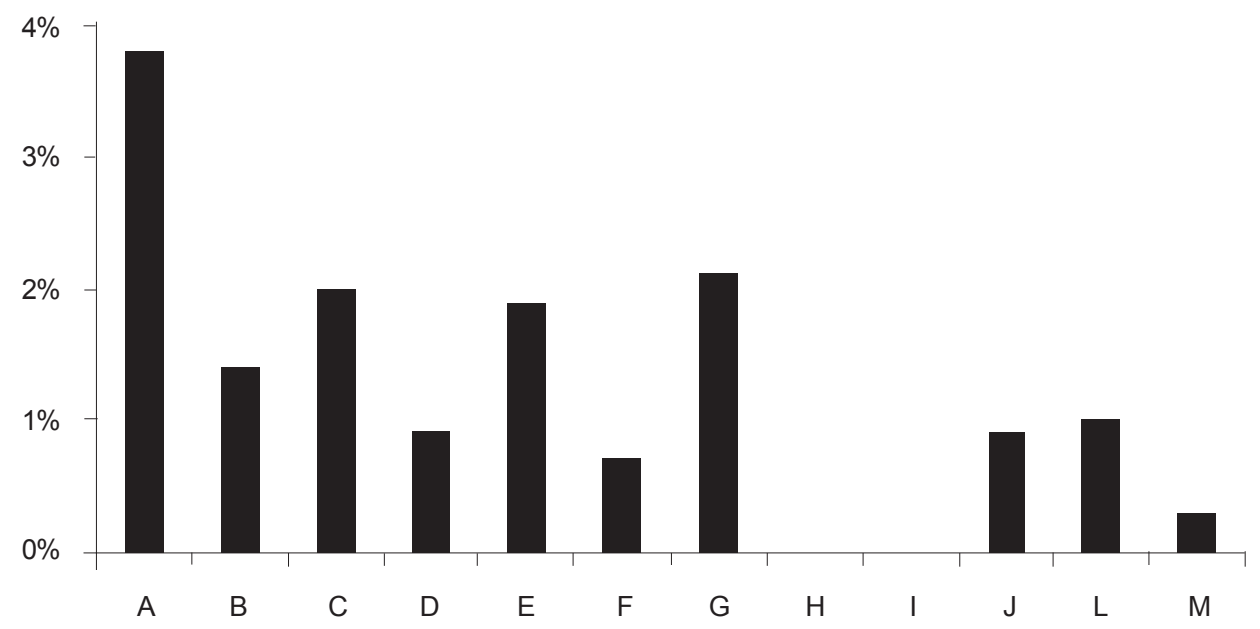

Figura 1. Espaço destinado à abordagem dos temas da Nova Biologia em cada exemplar - de Aa M. 


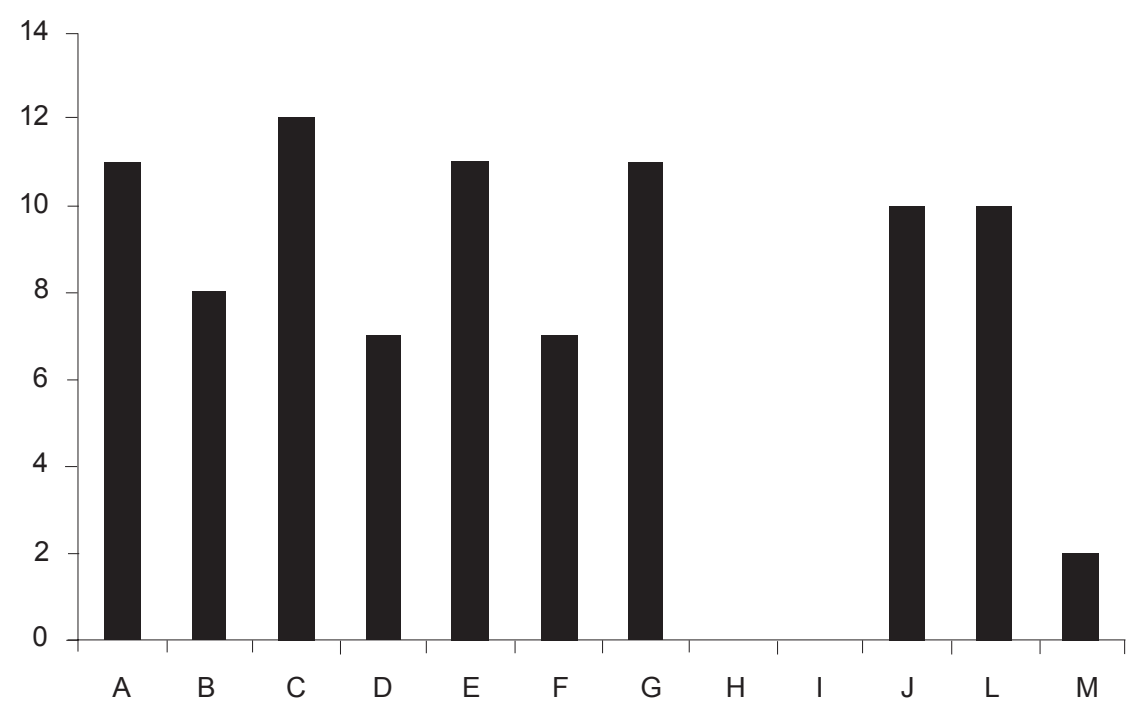

Figura 2. Quantidade de temas inseridos em cada exemplar de A a M ( $n=15)$.

\section{Como são abordados os temas da Nova Biologia nos livros didáticos?}

O tema DNA recombinante foi o mais reincidente, dez vezes (Tabela 2). Melhoramento genético e enzimas de restrição aparecem nove vezes; transgênicos e clonagem de mamíferos ocorrem oito vezes; projeto genoma, teste de paternidade e plasmídeos, sete vezes. Variabilidade genética surge seis vezes, seqüencionamento e eletroforese possuem cinco ocorrências, célulastronco ocorre três vezes; hibridação, íntrons E éxons e PCR possuem duas ocorrências.

O espaço dedicado a cada tema e o número de vezes em que ele foi mencionado também foram objeto de análise (Tabela 2). Observa-se que os temas mais presentes nos livros didáticos são: transgênicos, clonagem de mamíferos e melhoramento genético, únicos inseridos na categoria mais de duas páginas. Projeto genoma é um assunto que ocupa espaço razoável nos livros, de até duas páginas. Teste de paternidade e DNA recombinante receberam por parte de alguns livros espaço um pouco superior a uma página, inseridos na categoria até uma página e meia, mas também aparecem em outros no espaço de até uma página. Células-tronco e variabilidade genética aparecem em espaços até uma página, mas também inseridos em categorias de menor amplitude de espaço. Plasmídeos e eletroforese recebem textos até meia página e também pôde-se observar que temas como hibridação, enzimas de restrição, íntrons e éxons e PCR possuem textos de até dois parágrafos. O tema eletroforese, quando ocorre, dá-se apenas como citação, não recebendo nenhuma explicação mais detalhada. Uma outra abordagem a observar na Tabela 3 é a presença ou não de ilustrações referentes aos temas comparados à sua ocorrência.

Nota-se que os itens hibridação e plasmídeos são os únicos que possuem igual número entre ilustração e ocorrência nos livros, tendo os demais número menor de ilustrações com relação ao de ocorrências. 
Xavier, M. C. F. et al.

Tabela 2. Total de citações no texto e a relação espaço/ número por elas ocupado em cada categoria.

\begin{tabular}{lcccccccc}
\hline \multicolumn{1}{c}{ Temas } & $\begin{array}{c}\text { Citação } \\
\end{array}$ & $\begin{array}{c}\text { Até dois } \\
\text { parágrafos }\end{array}$ & $\begin{array}{c}\text { Até meia } \\
\text { página }\end{array}$ & $\begin{array}{c}\text { Até uma } \\
\text { página }\end{array}$ & $\begin{array}{c}\text { Até uma } \\
\text { pág. e meia }\end{array}$ & $\begin{array}{c}\text { Até duas } \\
\text { páginas }\end{array}$ & $\begin{array}{c}\text { Mais de } \\
\text { duas pág. ocorrências }\end{array}$ & $\begin{array}{c}\text { Total de } \\
\text { Transgênicos }\end{array}$ \\
\hline & 0 & 1 & 3 & 1 & 1 & 1 & 1 & 8 \\
Projeto Genoma & 0 & 0 & 1 & 1 & 1 & 4 & 0 & 7 \\
Clonagem de mamíferos & 1 & 2 & 1 & 1 & 1 & 0 & 2 & 8 \\
Células-tronco & 0 & 0 & 2 & 1 & 0 & 0 & 0 & 3 \\
Teste de paternidade & 0 & 1 & 1 & 4 & 1 & 0 & 0 & 7 \\
Variabilidade genética & 1 & 2 & 2 & 1 & 0 & 0 & 0 & 6 \\
Melhoramento genético & 1 & 2 & 1 & 2 & 1 & 1 & 1 & 9 \\
DNA recombinante & 2 & 3 & 1 & 2 & 2 & 0 & 0 & 10 \\
Hibridação & 1 & 1 & 0 & 0 & 0 & 0 & 0 & 2 \\
Seqüenciamento & 5 & 0 & 0 & 0 & 0 & 0 & 0 & 5 \\
Enzimas de restrição & 0 & 4 & 5 & 0 & 0 & 0 & 0 & 9 \\
Plasmídeos & 2 & 3 & 2 & 0 & 0 & 0 & 0 & 7 \\
Íntrons e éxons & 0 & 2 & 0 & 0 & 0 & 0 & 0 & 2 \\
Eletroforese & 3 & 1 & 1 & 0 & 0 & 0 & 0 & 5 \\
PCR & 0 & 1 & 0 & 1 & 0 & 0 & 0 & 2 \\
\hline
\end{tabular}

Tabela 3. Questões e ilustrações referentes a cada tema.

\begin{tabular}{lcc}
\hline \multicolumn{1}{c}{ Temas } & Questões & Ilustrações \\
\hline Transgênicos & 18 & 5 \\
Projeto genoma & 8 & 4 \\
Clonagem de mamíferos & 14 & 7 \\
Células-tronco & 4 & 1 \\
Teste de paternidade & 2 & 6 \\
Variabilidade genética & 1 & 0 \\
Melhoramento genético & 5 & 3 \\
DNA recombinante & 18 & 6 \\
Hibridação & 0 & 2 \\
Sequenciamento & 1 & 1 \\
Enzimas de restrição & 4 & 7 \\
Plasmídeos & 2 & 7 \\
Íntrons e éxons & 0 & 2 \\
Eletroforese & 2 & 3 \\
PCR & 0 & 1
\end{tabular}

As atividades relativas a cada item também foram observadas, destacando transgênicos e DNA recombinante como os assuntos mais contemplados nos exercícios, presentes em 18 questões, e seguidos pela clonagem, presente em 14 exercícios. O tema Projeto Genoma apareceu 
em oito atividades; melhoramento genético em cinco; células-tronco e enzimas de restrição em quatro. Apenas duas atividades estavam relacionadas ao teste de paternidade, plasmídios e eletroforese. Variabilidade genética e seqüenciamento aparecem em apenas uma atividade; e hibridação, íntrons e éxons e PCR não são contemplados em nenhuma atividade.

Também foi alvo da pesquisa a inserção de outras fontes de estudo nos textos didáticos, demonstrando que elas contribuem para a redação dos textos de áreas mais modernas. Apenas três exemplares (A, C e E) as usaram. O livro A utilizou textos do jornal Folha de São Paulo e também de revistas científicas, como Nature, ou de divulgação científica, Ciência Hoje e Galileu. O exemplar C apenas relata textos do jornal O Estado de São Paulo, enquanto que o livro E utilizou o jornal O Globo e o livro "Genética moderna”, de Griffiths et al. (2001).

Outro dado foi que apenas dois exemplares (A e H) relatam estarem de acordo os PCNEM, teoricamente atestando bom nível de atualização. Curiosamente, o exemplar H não trata de nenhum dos temas da pesquisa.

\section{Que espaço ocupa nos livros o tema Genética Clássica?}

Para análise comparativa de dados, quantificou-se quanto do espaço de cada exemplar pesquisado é dedicado aos temas da Genética Clássica (Figura 3).

Dos 12 exemplares pesquisados, apenas um dedicou 3,8\% de seu espaço para discussão dos temas, ficando a grande maioria em torno de $2 \%$ a $1 \%$. A Genética Tradicional, inclusa nas escolas desde muito tempo, tem espaços fartos dedicados a seu estudo, chegando a até $20 \%$ do livro didático.

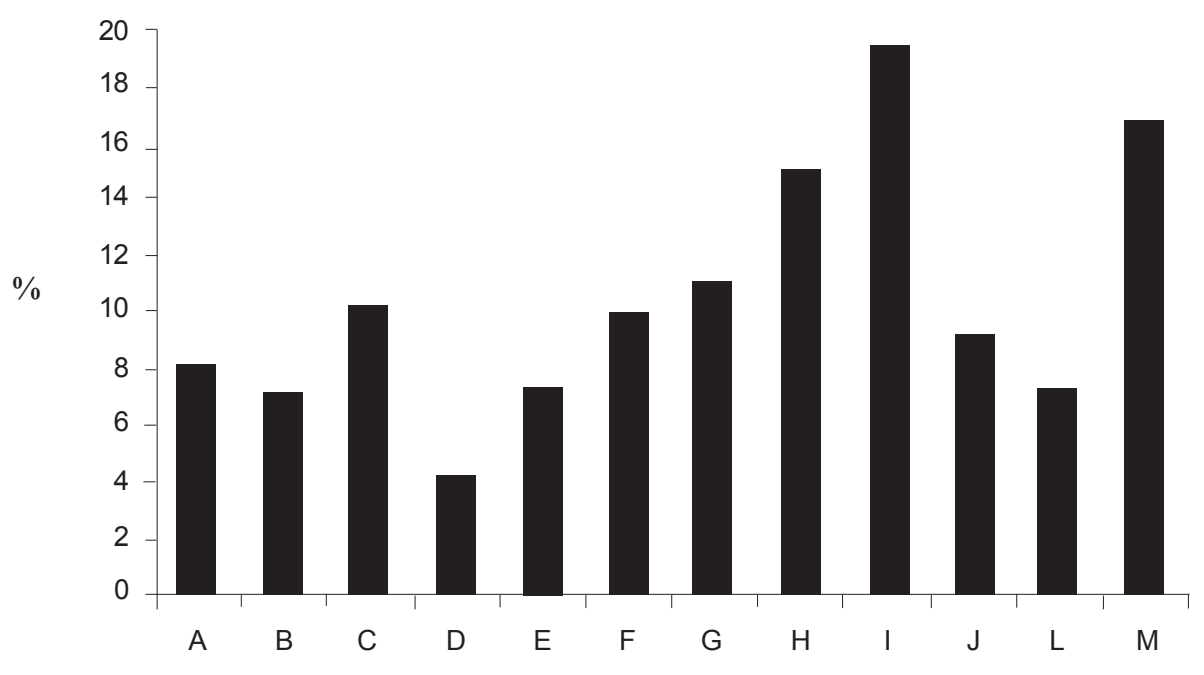

Figura 3. Espaço destinado em cada exemplar para os temas tradicionais em Genética. 
Neste item em particular, o livro I destaca-se por dedicar 19,5\% de suas páginas à Genética Clássica. Este dado foi conseguido pela razão entre as páginas dedicadas a esse conteúdo pelo número total destas na obra como um todo. O livro $\mathrm{M}$ dedica $16,6 \%$ de seu espaço ao tema e o livro H, 15\%. Seguem o livro G, com 10,8\%, C, com 10\%, F, com 9,8\%, J, 8,9\% , e o livro A, 8\%. Os livros E e L dedicam 7\% de seu espaço, B destina 6,8\% e o livro D, 3,8\%. Verificou-se que dos 15 temas escolhidos apenas um exemplar aborda 12. Três exemplares abordam 11 temas, dois abordam dez, um aborda oito, dois citam sete temas e um, dois.

\section{Discussão}

A pergunta sobre o que ensinar ainda persiste. A questão é como conciliar o tempo exíguo com o cada vez mais extenso programa. Paralelamente a essa discussão, as novidades associadas à Biologia invadiram a sociedade e necessitam de discussão e urgente compromisso da escola. Surge, então, o livro didático como ferramenta importante neste contexto. O ensino, especificamente da Nova Biologia, deveria se apresentar nas escolas como uma ferramenta apta a inserir alfabetização científica e tecnológica (Núñes e Franco, 2001). Como garantir qualidade em conteúdo, abrangência, atualização e atividades de fixação, requisitos de extrema valia no processo ensino-aprendizagem? Sendo alvo de pesquisas nas quais se apontem erros e soluções propostas. O livro didático é uma ferramenta importante no processo de ensinoaprendizagem embora, em alguns casos, "não seja visto como um instrumento auxiliar na sala de aula mas, sim, como a autoridade, modelo da excelência a ser adotado em classe" (Freitag et al., 1997, p. 124). Além disso, mais recentemente, os livros-textos têm sido alvo de processamento sistemático, que edita o conteúdo e utiliza apenas o essencial (Neto e Francalanza, 2003).

Os resultados mostram que os livros didáticos de Biologia são, de maneira geral, pouco atualizados (estão defasados/estão muito aquém) em relação aos temas da Nova Biologia. No entanto, continuam sendo a espinha dorsal do currículo na maioria das escolas, mas é bem pouco provável que a Nova Biologia esteja sendo trabalhada de maneira significante para os alunos. A análise realizada permite avaliar unicamente presença e atualização de conteúdo nos livros didáticos e uma avaliação mais detalhada poderia contemplar a forma como os parcos conteúdos da Nova Biologia estão sendo utilizados em sala de aula.

A maioria dos professores baseia sua organização de aulas em livros didáticos, mesmo que eles não estejam inseridos no cotidiano escolar, fazendo deles um autêntico "diário de bordo", no qual os conteúdos a serem trabalhados são ali estudados mecanicamente. Seu uso foi também sinalizado como interferente de modo significativo no dia-a-dia da sala de aula, sendo o livro escolhido aquele mais adequado ao nível social dos alunos. A escolha resultante é de um livro de volume único, de menor custo e, conseqüentemente, menor conteúdo. Em algumas situações, cópias ou apostilas (leia-se coletâneas de textos de outros livros) são utilizadas, fragmentando ainda mais o ensino. No final o resultado é previsível: menor apropriação de conteúdos (Xavier et al., 2005). 
Neste contexto Loreto e Sepel (2003, p. 151) afirmam:

Ter uma visão contemporânea de como somos e como funcionamos é um direito de todo cidadão e entendemos que seja, também, uma obrigação do estado. Somente de posse de um conhecimento atualizado podemos ser críticos em relação às informações que recebemos.

A escola precisa estar inserida plenamente nesta nova era em que o DNA e suas conseqüências surgem nos meios de comunicação. Os temas abordados na pesquisa refletem as novas tecnologias que já se encontram inseridas no mundo científico desde o final da década de 1970 (Moraes, 2003) e a busca nos livros de sua presença reflete que o livro didático, mesmo sendo atual, mantém uma distância entre o conhecimento produzido e os conhecimentos divulgados (Reznik, 1995).

De forma geral, a avaliação demonstra que os atuais livros excluem objetivos educacionais importantes referentes à Nova Biologia, influenciando sobremaneira o sucesso da contextualização e impedindo que o aluno sinta-se seguro para emitir julgamento ou opinião a respeito de temas socialmente relevantes.

Os temas selecionados englobam os saberes mínimos para uma postura de julgamento perante questões sociais relevantes dentro dos temas da Nova Biologia. Alguns deles, como enzimas de restrição, mereceram apenas algumas linhas e, por isso, foram incluídos naqueles citados no espaço de até dois parágrafos. Já outros temas, como seqüenciamento e eletroforese, são somente citados, sem constar uma explicação sequer. É relevante concluir também que a análise quantitativa pôde apenas avaliar o espaço dedicado a cada um dos temas propostos. É possível que para alguns deles (como enzimas de restrição, por exemplo) o espaço ocupado seja suficiente para a boa apropriação dos conteúdos. Porém, para outros, como Projeto Genoma, apenas o espaço de até meia página distancia em muito do necessário ao bom entendimento, para o que poderiam ser incluídos ilustrações, exemplos, explicações mais dedicadas etc. Tal abordagem desvaloriza o livro didático, considerado por Vasconcelos e Souto (2003) um dos fatores de formação do aluno, juntamente com os professores, as práticas pedagógicas e condições sócio-econômicas. O tema seqüenciamento é o único que recebe por parte dessas obras apenas uma palavra, uma citação mas nenhuma explicação, deixando, assim, de ser parte fundamental do entendimento mais profundo de outros itens correlatos.

Ao cruzar esses dois dados obtidos (espaço e o número de itens abordados em cada exemplar) causa estranhamento verificar que o livro A destina 3,8\% de suas páginas a 11 dos 15 temas, mas os livros $\mathrm{G}$ e $\mathrm{E}$ abordam o mesmo número de temas destinando, para isso, 2\% de seu espaço. $\mathrm{O}$ livro $\mathrm{C}$ aborda 12 temas, mas destina apenas $2 \%$ de suas páginas a eles. $\mathrm{O}$ livro J ocupando $0,9 \%$ com dez itens citados, assim como L, com $1 \%$. Outro livro aborda dez dos 15 itens destinando para isso apenas $0,9 \%$ de suas páginas. Considerando a abordagem incipiente da Nova Biologia nos livros didáticos analisados, cabe indagar: que tipo de abordagem está sendo feita? O aluno está realmente possuindo referenciais importantes para se posicionar perante os novos saberes? O livro D aborda sete itens, mas para isso destina os mesmos $0,9 \%$ que o livro J, que aborda dez itens. Os dados em relação à porcentagem dos temas da Nova Biologia, juntamente com o número de páginas dedicado a cada um dos temas, mostra que o livro A aborda menos assuntos, mas o faz de forma mais ampla, enquanto que a maioria dos 
livros (nove) parece inserir os temas sem preocupação de aprofundamento, apontando para uma inserção feita apenas para, aparentemente, estar de acordo com os PCNEM. Desta forma, observa-se que alguns livros prejudicam o entendimento e a qualidade dos temas devido à superficialidade da abordagem, enquanto outros acabam introduzindo poucos dos conteúdos necessários ao entendimento dos novos conceitos de Biologia. Estes resultados estão de acordo com Amaral e Megid-Neto (1997), que observam nos livros de Ciências que a atualização é introduzida apenas na apresentação das obras. Estamos no final de 2006 e as atualizações são as mesmas feitas em 1997.

Observamos que esses temas foram inseridos no final do capítulo referente à Genética. Se o conteúdo de Genética contido nos livros não é abordado na sua totalidade (Xavier et al., 2005) , cabe a pergunta: será que a Nova Biologia conseguirá abrir espaço entre o estudo das leis de Mendel e a Genética Clássica? Ou ficará à margem do currículo adotado nos colégios, sendo vista como tema de pesquisa ou meramente abordada como fazendo parte das "curiosidades"?

O espaço de alguns desses temas, quando citados, foi muito inferior ao necessário mesmo àqueles que estão sendo explorados na mídia de modo superficial. Pôde-se observar este dado ao analisar as citações que cada tema recebe. O Projeto Genoma, por exemplo, só ocorre em metade dos exemplares e, mesmo assim, ocupando de meia a duas páginas. O tema células-tronco, alvo de constantes debates, ocorre em apenas três exemplares e não perfaz o total de uma página completa. Clonagem é um tema que merece uma observação em destaque, mas ocorre em oito obras e de uma forma muito generalizada, sem profundidade. O espaço ocupado não condiz com sua importância reforçada, principalmente, nos PNLDEM. Parece que os autores percebem a necessidade explicativa do tema seqüenciamento, pois o inserem em textos ou ilustrações em cinco exemplares, mas não se preocupam na sua explicação, sendo o aluno, então, levado à leitura sem tê-la substanciado com seus conceitos. Além disso, alguns temas importantes, como plasmídeos e enzimas de restrição, são apenas mencionados. Tal abordagem revela-se sem substância capaz de ajudar o aluno a mudar sua realidade, ou seja, o aluno permanece sem as ferramentas capazes de o tornarem um cidadão crítico a respeito das novas informações que recebe. Afinal, como ter discernimento suficiente para tomada de decisão em relação a alimentos transgênicos, por exemplo, se não sabe o conteúdo mínimo relativo a este tema?

Assim, os livros mostram-se fracos no que tange sua participação no entendimento das novas tecnologias e dos demais processos de obtenção e do estudo do DNA e de suas aplicações, necessárias à Nova Biologia e à Biologia Molecular.

Quanto às ilustrações, quando estão presentes não apresentam vinculação com o texto de maneira adequada. Muitos assuntos, como seqüenciamento ou PCR, apresentam um número de ilustrações aquém da quantidade de vezes que é citado no texto. Assim, muitos livros suprimem as ilustrações, deixando o aluno sem referencial visual, forçando-o a encontrar somente na informação verbal o entendimento e a apreensão do tema, exigindo maior esforço de compreensão. Vale destacar o tema variabilidade genética, que possui seis citações nos livros mas não recebe nenhuma ilustração alusiva. O tema variabilidade genética, por exemplo, com seis citações ao todo, não é contemplado com qualquer ilustração, já o tema "seqüenciamento" foi ilustrado em um dos exemplares sem, no entanto, qualquer explicação. 
Assim como a informação verbal somente, sem ilustrações relacionadas, dificulta o processo de entendimento dos conceitos, também a ilustração por si só não esclarece o suficiente, os alunos saindo bastante prejudicados em um e em outro caso. Em relação às atividades de fixação, que colaboram para a absorção do conteúdo estudado, os temas "transgênicos", "DNA recombinante" e "clonagem" são os únicos que receberam 18 e 14 questões, ficando a grande maioria dos demais com poucas ou nenhuma questão de fixação.

Observando com o olhar voltado para a Genética Clássica destaca-se o livro I, que dedica o montante de 19,5\% de seu espaço para tal disciplina. Nada aborda sobre a Nova Biologia, apesar de ter sido editado em 2002. O mesmo acontece com o livro H, que destina $15 \%$ para a Genética e nada para a Nova Biologia. O exemplar M dedica apenas 0,3\% de espaço à Nova Biologia e 16,6\% para a Genética Clássica. Estes exemplares parecem refletir a preocupação em incutir no aluno apenas o referencial genético clássico, sem ampliar os temas, atualizar as informações em Genética e contextualizá-la com as novas tecnologias.

\section{Conclusões}

Ao final desta pesquisa percebeu-se que os livros didáticos necessitam de reformulação. Sabe-se que eles são de extrema valia e importância no cenário educacional público e privado mas é necessário que sofram atualizações e ampliação de conteúdos, lançamento de textos mais contextualizados, reestruturação de capítulos promovendo novas formas de inserir os temas modernos. Que os temas da Nova Biologia possam ser totalmente inseridos e abordados na medida adequada para solidificar seu aprendizado. A ampliação de temas importantes, como células-tronco, Projeto Genoma, paternidade por DNA, entre outros, será necessária. É notável observar que, em se tratando do DNA, hoje as novas tecnologias já marcam definitivamente novas relações na Biologia. Podemos perceber que o estudo evolutivo faz-se com a presença de marcadores de DNA e novas espécies são identificadas, reformulando conceitos e classificações em Botânica e Zoologia, inclusive a Sistemática. Novos saberes surgem na Biologia Celular e Histologia, entre outros. E os alunos? Não será a eles permitido participarem dessas inovações? Deve-se ter em conta que a Biologia e suas disciplinas afins são mutantes, agregam constantemente novidades que alteram de alguma forma seus conteúdos e estes precisam ser incluídos na escola. Os educadores devem, então, lutar para que o material educativo e didático seja alvo de constantes reformulações.

O processo de construção de livros didáticos que ampliem conteúdo é árduo. Porém, os temas multi ou transdisciplinares que estão sendo recortados devem aproximar especialistas na tentativa de compor livros multi-autorais que sejam abrangentes, com linguagem simples e direta, para que cumpram o objetivo de serem fonte de consulta, organizadores de aulas, ordenadores de atividades.

Não se tem a pretensão de formar cientistas ou biólogos moleculares, mas pessoas capazes de entender o constante avançar do conhecimento científico (Reznik, 1995). Já que as novas perspectivas que apontam dizem respeito às várias questões de ordens sociais, religiosas, éticas e o aluno faz parte desse contexto ele precisa obter dados de conhecimento científico básico (Reznik, 1995) para se posicionar perante as inovações que farão parte da vida num 
Xavier, M. C. F. et al.

futuro bem próximo. Na verdade, este trabalho utiliza as novidades da Biologia como modelo. Com a aceleração do conhecimento e o desafio entre o ensino clássico e o moderno todas as áreas científicas devem sofrer mudanças conceituais.

\section{Referências}

AMARAL, I. A.; MEGID-NETO, J. Qualidade do livro didático de Ciências: o que define e quem define? Ciência \& Ensino, n. 2, p. 13-14, 1997.

BRASIL. SECRETARIA DE EDUCAÇÃO FUNDAMENTAL Parâmetros Curriculares Nacionais - Ensino Médio (PCNEM). Brasília: MEC/SEF, 2000.

FRANCO, M. L. P. B. O livro didático e o Estado. ANDE, ano I, n. 5, p. 19-24, 1992.

FREITAG, B.; COSTA, W. F.; MOTTA, V. R. O livro didático em questão. 3. ed. São Paulo: Cortez, 1997.

GAYÁN, E.; GARCÍA, P. E. Como escoger un libro de texto? Desarrollo de un instrumento para evaluar los libros de texto de ciencias experimentales. Enseñanza de las Ciencias, número extra, V Congresso, p. 249-250, 1997.

GRIFFITHS, A. J. F.; MILLER, J. H.; SUZUKI, D. T.; LEWONTIN, R. C.; GELBART, W. M.. An introduction to Genetic Analysis. 6. ed. Nova York: W. H. Freeman and Company, 2001.

LORETO, E. L. S.; SEPEL, L. M. N. A escola na era do DNA e da Genética. Ciência e Ambiente, v. 26, p.149-156, 2003.

MACEDO, E. Imagem e pesquisa em educação: currículo e cotidiano escolar: O livro didático como dispositivo curricular. Rev. Educação \& Sociedade, v. 25, n. 86, p. 15-16, 2004.

MINISTÉRIO DA EDUCAÇÃO E CULTURA DO BRASIL. Resolução/CD/ FNDE, n ${ }^{\circ}$ 003, de 21 de fevereiro de 2001. Disponível em: <http://www.fnde.gov.br>. Acesso em: mar. 2005 .

MORAES, M. O. Biologia Molecular na prática médica e biológica. Rio de Janeiro: Fundação Bio-Rio, 2003. 
A nova (moderna) Biologia e a genética...

MEGID-NETO, J.; FRANCALANZA, H. O livro didático de Ciências: problemas e soluções. Ciência \& Educação, v. 9, n. 2, p. 147-157, 2003.

NÚÑEZ, B. I.; FRANCO, S. O ensino por problemas: categorias e métodos. Natal, 2001. (mimeogr.).

NÚÑEZ, I. B.; RAMALHO, B. L.; SILVA, I. K. P.; CAMPOS, A. P. N. A seleção dos livros didáticos: um saber necessário ao professor. O caso do ensino de Ciências. Revista Iberoamericana de Educación, p. 1-12, 2003. Disponível em: < http://www.rieoei.org/deloslectores/427Beltran.pdf>. Acesso em: 10 fev. 2005.

REZNIK, T. O desenvolvimento do conceito de gene e sua apropriação nos livros didáticos de Biologia. Niterói, 1995. Dissertação (Mestrado) - Curso em Educação, Universidade Federal Fluminense, Rio de Janeiro, 1995.

VASCONCELOS, S. D.; SOUTO, E. O livro didático de Ciências no Ensino Fundamental proposta de critérios para análise do conteúdo zoológico. Ciência \& Educação, v. 9, n. 1, p. 93-104, 2003.

XAVIER, M.C.; FREIRE A. S.; MORAES, M.O. A introdução dos conceitos de Biologia Molecular e Biotecnologia no Ensino de Genética no Nível Médio: há espaço para a nova Biologia? In: ENCONTRO NACIONAL DE PESQUISA EM EDUCAÇÃO EM CIÊNCIAS, 5., Bauru, Atas... Bauru: Abrapec, 2005.

Artigo recebido em abril de 2006 e aceito em outubro de 2006 